УДК 781.1

DOI https://doi.org/10.31723/2524-0447-2021-32-2-8

\author{
Олександр Олександрович Корчев \\ ORCID: 0000-0002-7455-5610 \\ аспірант кафедри теорії музики
}

Національної музичної академії України імені П. І. Чайковського

teoralkor@gmail.com

\title{
ВИЯВЛЕННЯ ІДЕЇ ВИДОЗМІНИ ЯК ПРОЦЕСУ БЕЗПЕРЕРВНОЇ ТРАНСФОРМАЦІЇ ТЕМИ У ФОРТЕПІАННОМУ ЦИКЛІ «МЕТАМОРФОЗИ» ДЖОНА КЕЙДЖА
}

\begin{abstract}
Мета роботи - розкрити зміст поширеної в композиторській практиці XX-XXI століть ідеї метаморфози на прикладі фортепіанного ииклу Дж. Кейджа. Мета роботи зумовила такі завдання: окреслити жканрову палітру музичних творів із назвою «Метаморфози», з'ясувати характер утілення означеної ідеї; дослідити підходи до визначення явища метаморфози шляхом співвіднесення даної концепиії з низкою усталених понять у сфері теоретичного музикознавства, зокрема принципу проростання В. Протопопова, техніки «серійної фрагментації, що наводить О. Григоренко, а також терміна «дериваціі», до якого звертається М. Арановський у праці «Музыкальный текст. Структура и свойства»; шляхом иілісного аналізу фортепіанного опусу Джк. Кейджса окреслити основні засоби вираження ідеї видозміни у проиесі становлення композиції ииклу. Методологія дослідження: системний метод - дає можливість співвіднести багатовекторну композиторську концепцію «метаморфози» із низкою актуальних понять теоретичного музикознавства; історичний метод - розкриває ретроспективу поширення ідеї метаморфози у творчості композиторів ХХ-ХХІ століть; метод структурного аналізу - дозволяє простежити за розвитком вихідної теми фортепіанного ииклу Дж. Кейджа, розглянути особливості становлення музичного матеріалу твору, дослідити характерні ознаки функціювання приниипу «деривацї». Наукова новизна полягає в дослідженні ідеї «метаморфози», що є актуальною для творчості композиторів XX-XXI століть, висвітленні особливостей функціювання «деривації» на прикладі становлення музичного тексту фортепіанного ицклу Джс. Кейджа “Metamorphosis”, виявленні характерних ознак функціонування даного принципу в композиції музичного твору. Висновки. Результати цілісного аналізу фортепіанного циклу дозволяють означити вихідну тему як тематичне джерело, що стає основою для музичного матеріалу всього твору. Становлення композиції
\end{abstract}

(C) Корчев О. О., 2021 
являє собою процес безперервної трансформації теми, що приводить до ї̈ нового, видозміненого звучання у фінальній частині.

Ключові слова: метаморфози, ідея видозміни, процесуальність, проростання, Дж. Кейдж.

Korchev Oleksandr Oleksandrovych, Postgraduate Student at the Department of Music Theory of the Ukrainian National Tchaikovsky Academy of Music

Identifying the idea of modification as a process of continuous transformation of the theme in the piano cycle "Metamorphosis" by John Cage

Research objective. The purpose of the work is to reveal the content of the $X X-X X I$ centuries common in composition practice. ideas of metamorphosis, for example, on the example of the piano cycle by J. Cage. The purpose of the work led to the following tasks: outline the genre palette of musical works called "Metamorphoses", to find out the nature of the embodiment of this idea; investigate approaches to defining the phenomenon of metamorphosis by correlating this concept with a number of established concepts in the field of theoretical musicology, in particular the principle of germination of $V$. Protopopov, the technique of "serial fragmentation" given by O. Grigorenko, as well as the term "derivation" Aranovsky in the work "Musical text. Structure and properties"; through a holistic analysis of J. Cage's piano opus, outline the main means of expressing the idea of change in the process of forming the composition of the cycle. The methodology: systemic - gives the opportunity to correlate the multi-vector compositional concept of "metamorphosis" with a number of relevant concepts of theoretical musicology; historical - reveals a retrospective of the spread of the idea of metamorphosis in the works of composers of the $X X-X X I$ centuries; method of structural analysis - allows you to follow the development of the original theme of the piano cycle of J. Cage, to consider the features formation of the musical material of the work, to explore the characteristic features of the functioning of the principle of "derivation". The scientific novelty lies in the study of the idea of "metamorphosis", which is relevant to the work of composers of the $X X-X X I$ centuries, highlighting the features of the "derivation" on the example of the musical text of J. Cage's piano cycle "Metamorphosis", identifying the characteristics of this principle in the composition of musical work. Conclusions. The results of a holistic analysis of the piano cycle allow us to identify the original theme as a thematic source, which becomes the basis for the musical material of the whole work. In this case, the formation of the composition is a process of continuous transformation of the theme, which leads to its new, modified sound in the final part.

Key words: metamorphoses, idea of modification, procedurality, germination, D. Cage.

Виклад основного матеріалу. Серед надзвичайної різноманітності творів сучасної академічної музики помітне місце належить творам під назвою «Метаморфози», які окреслюють один із векторів у широкому просторі тематики музичного 
мистецтва XX - початку XXI ст. Виходячи з етимології слова (гр. methamorphosis - «перетворення», meth (а) - між- , nicля, yслід за - і morphe - «форма»), в енциклопедіях та словниках зміст поняття «метаморфози» визначається як «перетворення, видозмінення». У сфері композиторських концепцій даний термін, незважаючи на його семантичну спадкоємність (літературні, природознавчі дисципліни), став свого роду «спільним знаменником» для різних музичних творів. Маючи «спільне» найменування, усі вони розрізняються за жанром (балет, симфонічна сюїта, варіації, фортепіанні цикли й інші), образним змістом, художньою концепцією, композиторською технікою, що вказує на оригінальність утілення означеної в їх найменуванні ідеї «метаморфози». У сюїті Бенджаміна Бріттена - це програмне посилання на літературне першоджерело, а саме поему Овідія; у Джона Кейджа або Філіпа Гласса - це заголовок фортепіанного циклу; у Пауля Гіндеміта, Томаса Конроя, Левка Колодуба й Отторіно Респігі під цією назвою маються на увазі симфонічні твори зі спільною для них ідеєю «перетворення» (з використанням запозичених тем у творах Л. Колодуба, П. Гіндеміта та Т. Конроя і власної теми у варіаціях О. Респігі).

Яскравий приклад утілення даної ідеї можна знайти у творчості Дж. Кейджа, що увійшов в історію сучасного мистецтва як надзвичайно яскравий новатор і оригінальний експериментатор. Зокрема, з його ім'ям пов'язані відкриття в галузі тембру, ритму, звуковисотності, форми, нотації тощо. У своїй творчості Дж. Кейдж звертався до таких принципів композиції, як додекафонія, техніка 25-звукових хроматичних рядів, сонористика, алеаторика, репетитивність тощо. Початковим етапом освоєння методів композиції, можливостей організації і розвитку музичного матеріалу була 12-тонова техніка, з основами якої Дж. Кейджа ознайомив відомий піаніст Р. Булиг.

У серійній техніці із застосуванням 12-тонового ряду написана Соната для кларнету-соло (1933 р.), а також інші твори раннього періоду, у яких Дж. Кейдж вільно оперує додекафонним принципом (допускає повтори, використовує звукоряди, які не збігаються із 12-тоновим рядом тощо). Прагнучи створити свою техніку серійного письма, Дж. Кейдж винайшов «метод 25-тонового ряду», згідно з яким «кожний голос повинен діяти у відведеному йому діапазоні двох октав 
за обов'язкової умови послідовного вичерпання всіх двадцяти п’яти тонів $(24+1)$, перш ніж буде допущений повтор» [3, с. 19].

«Техніка серійної сегментації» (за визначенням О. Григоренко [3, с. 21]) стала наступним винаходом, що спирається на принцип серійності. На іiі основі були написані фортепіанний цикл «Метаморфози» (“Metamorphosis”), Три п'єси для дуету флейт, Музика для дерев'яних духових, вокальний цикл «П'ять пісень для контральто» та інші опуси, створені до кінця 1938 р. У цих творах в умовах вільної додекафонії композитор використовує повторність висотних рядів із ритмічним варіюванням або ритмічну повторність із зміною висот. Розкриваючи сутність зазначеної техніки, Дж. Кейдж зазначав: «<...> Моє головне завдання полягало не в тому, щоб зробити ряд помітним, а щоб замаскувати його, навіть зважаючи на е, що він був використаний як основа всього методу. Для досягнення цього я розподілив дванадцять тонів на невеликі групи; кожна група мала залишатися незмінною, тобто не варіюватися. Я брав ці групи тонів і розміщував <...> згідно з первісною формою або інверсією чи ракоходом або ракоходом інверсії. У кінці кожної групи були всі ці варіанти» [3, с. 21]. О. Григоренко зауважує, що в техніці серійної фрагментації серія відступає на другий план, стає номінальною абстракцією, а на перший план виходять прийоми, засновані на принципах фрагментації (серія розпадається на фрагменти), репетитивності (повторення фрагментів) та комбінаторики (комбінування фрагментів у різній послідовності) [3, с. 22].

Одним із показових прикладів утілення зазначених принципів композиційної організації виступає фортепіанний цикл "Metamorphosis", що складається 3 п'яти мініатюр. В основі його композиції лежить серія з п'яти звуків $(\mathrm{d}-\mathrm{e}-\mathrm{h}-\mathrm{b}-\mathrm{as})$. Розгортання музичного матеріалу пов'язане з безперервним процесом видозмінення теми - «зерна», 3 якого виростає весь тематизм циклу. Ї̈̈ ключовою інтонацією $є$ висхідний стрибок на квінту з його заповненням низхідним рухом «півтон - тон».

У першій п’єсі тема відразу подається в розвитку (чотири секвенційні проведення теми від тонів d, c, es, g із незмінною інтонаційною структурою). 
Приклад 1. Дж. Кейдж. Фортепіанний цикл «Метаморфози» (с. 10)

\section{METAMORPHOSIS}

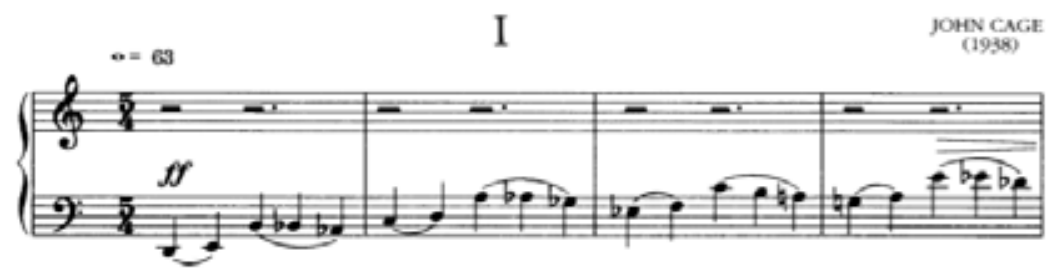

Безперервний регулярний рух чвертками у швидкому темпі, що викликає асоціації 3 perpetuum mobile, утворює наскрізну лінію розгортання, у яку вплітаються нові, похідні тематичні варіанти. Вони утворюються шляхом звуковисотних змін та регістрового розташування тонів теми, незначного варіювання iï інтонаційної структури, інверсії. Таким способом нові варіанти теми поступово віддаляються від свого первісного вигляду і самі стають інтонаційними зернами, що породжують нові тематичні утворення. Загалом, процес «тематизації» охоплює всю музичну тканину твору - у iï горизонтальному, діагональному та вертикальному вимірах, а саме:

1. Одноголосся та комплементарне двоголосся в першому розділі, у рамках якого композитор рівномірно розподіляє «мобільні» сегменти теми, що перебувають у процесі розвитку.

2. Акордова та гомофонно-гармонічна (умовно) фактура середнього розділу постає своєрідним структурним центром музичної тканини першої частини циклу (т. 43).

3. Комплементарне двоголосся в репризі.

Зазначимо, що фактурна організація першої п’єси вибудовується за концентричним принципом - від одноголосся до акордового викладу з наступним поверненням до одноголосся. Водночас у результаті безперервного оновлення породжується значна кількість похідних варіантів основної теми, що вплітаються у процес тематичного розгортання першої «Метаморфози». Це відбувається шляхом комбінаторних перестановок тонів теми, звуковисотного та регістрового варіювання. 
Друга п’єса циклу має спокійний характер (четвертна нота $=184)$. Вона розпочинається 3 викладу теми у збільшенні (від тону еs) і доповнюється новим мотивом, побудованим на пульсуючому ритмі інтонації малої секунди (т. 3)

Приклад 2. Дж. Кейдж. Фортепіанний цикл «Метаморфози» (с. 16, тт. 1-3)

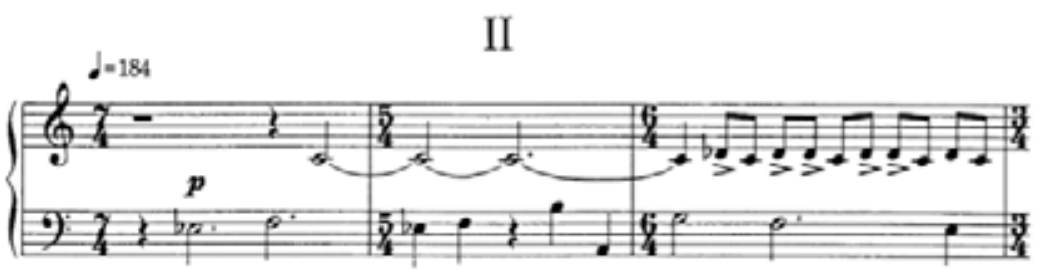

Цей мотив виконуватиме важливу наскрізну роль у композиції всього фортепіанного циклу. У другій «Метаморфозі» тема-інваріант отримує нове метроритмічне вирішення. На відміну від дещо одноманітної пульсації вихідної теми, ритмічна організація цієї п’єси відзначається більшою складністю та різноманітністю. Перемінний розмір (7/4-5/4-6/4-3/4-5/4...), синкопований ритм, ритмічні фігури 3 нерівними тривалостями в розмірі $7 / 4$ - усе це надає звучанню теми гротескного характеру (що особливо відчутно в тт. 35-39).

Основою тематичного розгортання другої п'єси виступає малосекундовий мотив (т. 3). У процесі розвитку він зазнає різних інтонаційних перетворень: подається у вертикальному вигляді (ч. 4, м. 7) на контрастній динаміці, що регулярно змінюється від $p$ до $f f$ (тт. 13-14).

Приклад 3. Дж. Кейдж. Фортепіанний цикл «Метаморфози» (с. 16, тт. 11-17)
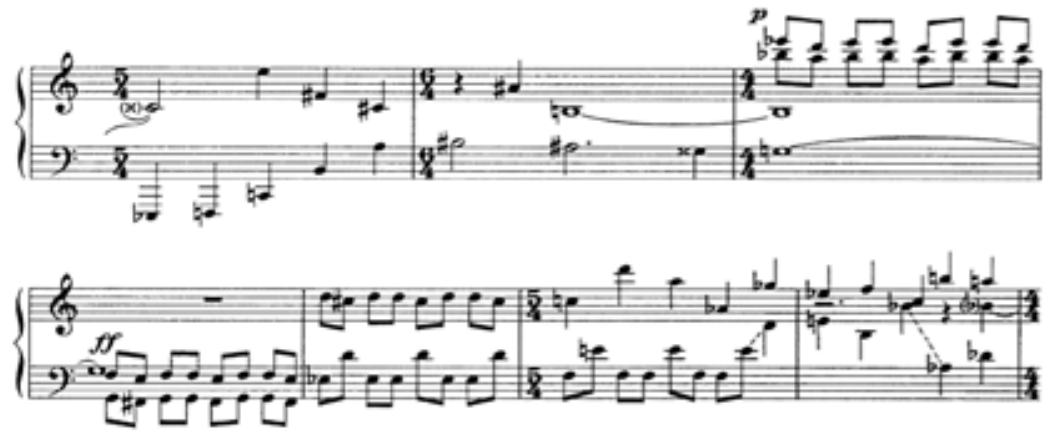
У наступному перетворенні інтонація м. 2, що лежить в основі мотиву, унаслідок обернення перетворюється на в. 7. У такому вигляді цей варіант поєднується з вихідним мотивом і одним із трансформованих варіантів заголовкової теми циклу (тт. 15-16). Ще один варіант цього мотиву пов'язаний із його трансформацією м. 2 у м. 9 (тт. 19, 23).

Приклад 4. Дж. Кейдж. Фортепіанний цикл «Метаморфози» (с. 17, тт. 18-23)
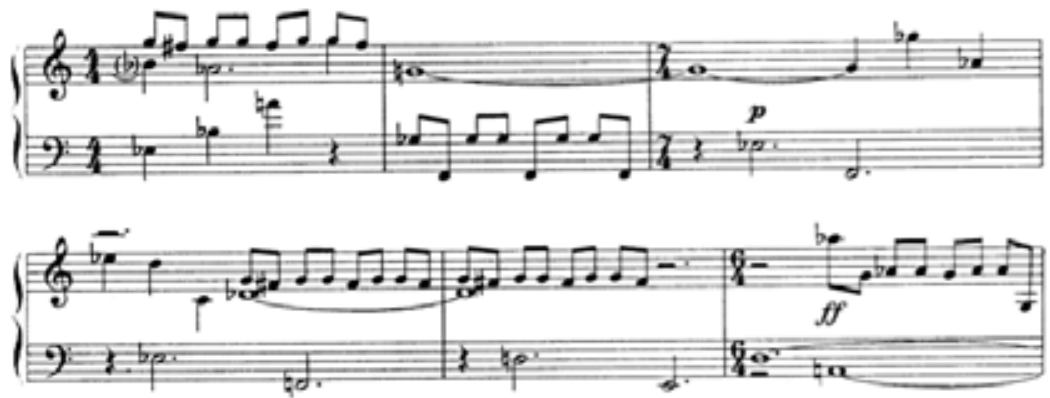

Тема-інваріант «Метаморфоз», яка була представлена в першій п'єсі, розгортається протягом усього циклу в усе нових варіантах. Одні з варіантів повторюють ритмо-інтонаційну структуру інваріанту, інші значно оновлюються ритмічно і звуковисотно (тт. 36-39, низхідний варіант - тт. 59-60).

Приклад 5. Дж. Кейдж. Фортепіанний цикл «Метаморфози» (с. 19, тт. 59-62)

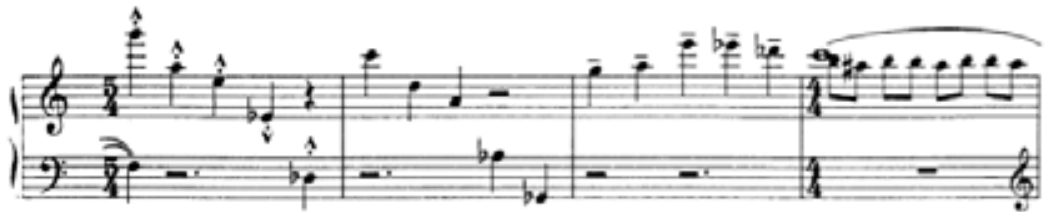

Загалом в основі розгортання тематичного матеріалу другої п’єси лежить процес безперервної зміни всіх параметрів структури теми-інваріанту (на рівні звуковисотності, ритму, фактури, регістру, динаміки) і нового мотиву, який з'являється у другій п'єсі. Отже, на взаємодії цих двох тематичних комплексів побудована композиція другої «Метаморфози». 
На початку третьої п'єси циклу інтонаційна структура теми-інваріанту виступає в новому вигляді. Застосування прийому інтерполяції (заміна тону $f$ на $a$ ), комбінаторної перестановки звуків із підкресленням ходів на тритон у поєднанні з низьким регістром та повільним темпом надають темі загадкового, таємничого звучання.

Приклад 6. Дж. Кейдж. Фортепіанний цикл «Метаморфози» (с. 20, тт. 1-4)
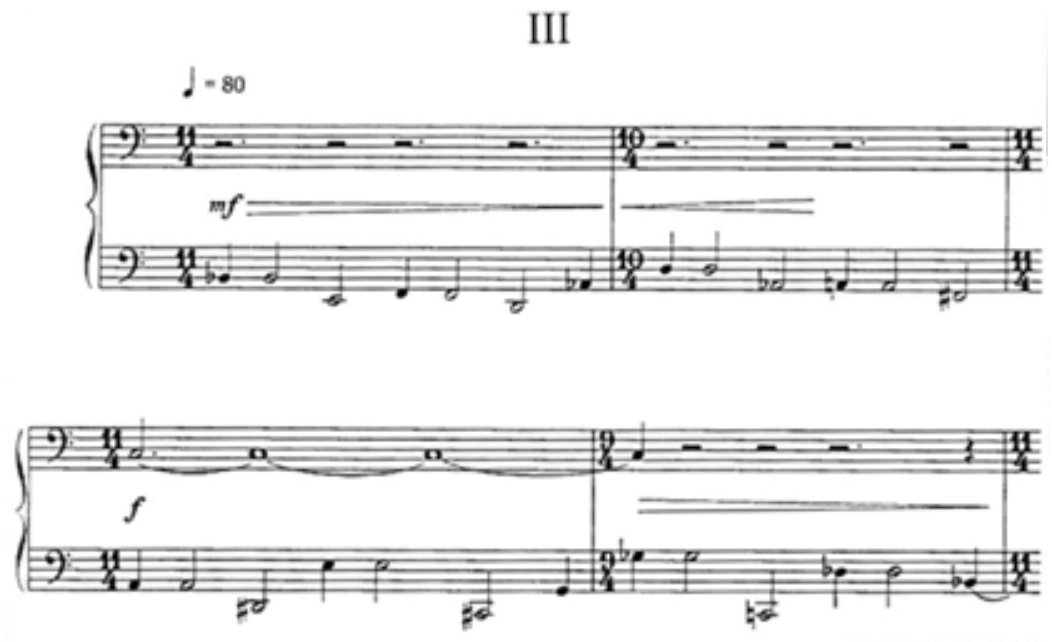

Часовий вимір тематичних перетворень має змінний характер. Це яскраво проявляється у варіантній зміні метроритму в кожному такті попарно організованої тактової структури: 11/4-10/4-11/4-9/4-11/4-8/4-11/4-7/4...1/4. Звертає на себе увагу регулярність чергування стабільного і мобільного елементів цієї числової прогресії, де стабільним членом прогресії виступає розмір 11/4 (перший у кожній парі тактів), тоді як у кожному другому такті відбувається зміна розміру з поступовим зменшенням показника на мінус один у чисельнику дробу, яким позначається розмір, - загалом від 11 до 1 (11/4-10/4; 11/4-9/4; 11/4-8/4; 11/-7/4; .. 1/4). Отже, єдність і багатоманітність (тотожність і контраст, за Б. Асаф’євим), проявляються на всіх рівнях - композиційному, інтонаційно-тематичному, а у даному випадку - на рівні ритмічної організації твору. 
Контрапунктом до теми-інваріанту виступають похідні варіанти мало секундового мотиву другої п’єси, завдяки чому частини циклу інтонаційно пов'язуються одна з одною.

Тематичним зерном четвертої п'єси стає наскрізний малосекундовий мотив другої «Метаморфози». На його основі утворюються низхідні гамоподібні пасажі, викладені дрібними тривалостями. Завдяки швидкому темпу (чверть $=208$ ) і варіюванню динаміки звучання набуває жвавого, скерцозного характеру.

Приклад 7. Дж. Кейдж. Фортепіанний цикл «Метаморфози» (с. 24, тт. 1-2)
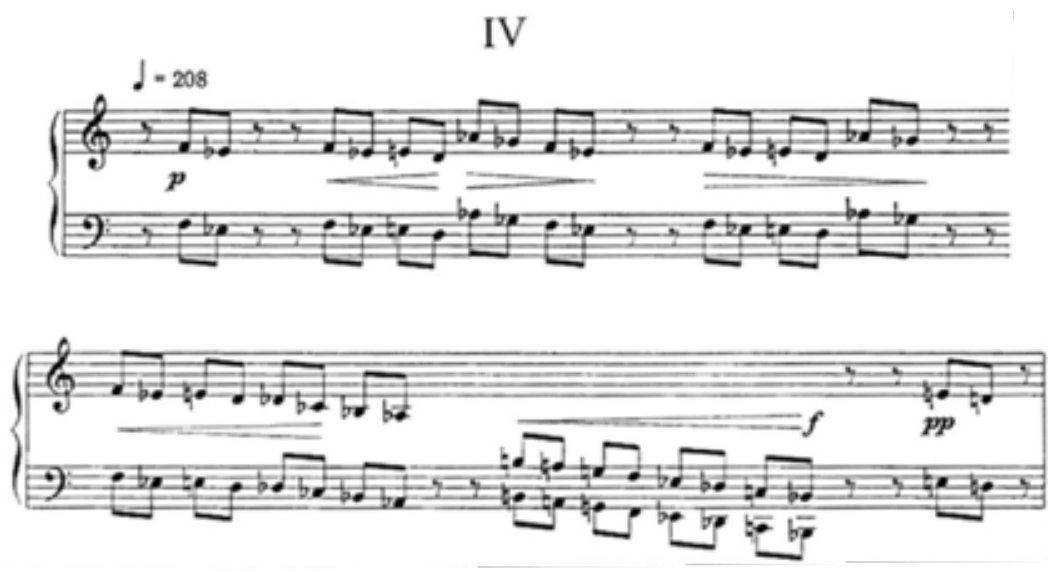

П'ята п’єса «Метаморфоз» Дж. Кейджа органічно вплітається в розгортання фортепіанного циклу завдяки інтонаційним зв'язкам з попередніми частинами. Зокрема, вагому роль у їі тематичному матеріалі відіграють гамоподібні ходи, а також секундові інтонації четвертої п’єси.

Водночас основна тема циклу виступає в редукованому вигляді: з неї виокремлюється заключний мотив (хід «півтон тон»), який завдяки новому ритмічному оформленню та комбінуванню тонів становить нову мотивну структуру, що стає тематичним зерном цієї мініатюри. Із цього зерна «проростають» нові варіанти теми. Саме на розгортанні похідних тематичних утворень та їхніх модифікаціях базується заключна частина «Метаморфоз». 
Приклад 8. Дж. Кейдж. Фортепіанний цикл «Метаморфози» (с. 28, тт. 1-7)
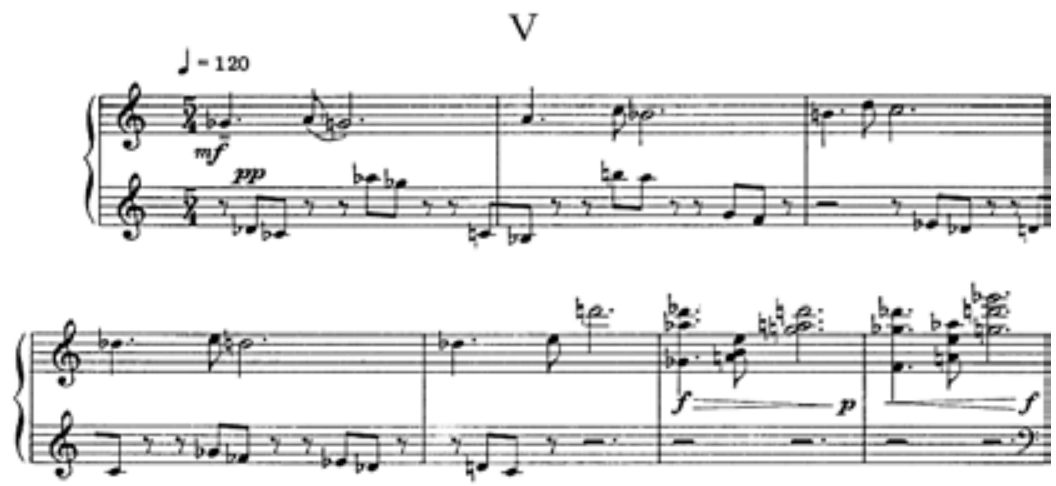

Отже, вихідна тема фортепіанного циклу Дж. Кейджа стає тематичним джерелом, з якого походить весь музичний матеріал твору. Становлення композиції являє собою процес безперервної трансформації теми, що приводить до їі нового, видозміненого звучання у фінальній частині.

Отже, в основі процесу трансформації теми у фортепіанному циклі Дж. Кейджа лежать такі принципи музичного розвитку:

1. Принцип проростання (В. Протопопов), згідно з яким тематичне ядро та його похідні варіанти, що утворюються у процесі розвитку завдяки постійній незначній варіантній змінності, ніби «проростають» із тематичного джерела і зливаються в єдине ціле.

2. Техніка «серійної фрагментації» (за визначенням О. Григоренко), композитор розкривав суть якої та зазначав: «<..> Моє головне завдання полягало не в тому, щоб зробити ряд помітним, а щоб замаскувати його, навіть зважаючи на те, що він був використаний як основа всього методу. Для досягнення цього я розподілив дванадцять тонів на невеликі групи; кожна група мала залишатися незмінною, тобто не варіюватися. Я брав ці групи тонів і розміщав <..> згідно з первісною формою або інверсією чи ракоходом або ракоходом інверсії. У кінці кожної групи були всі ці варіанти» [3, с. 21].

3. Зв'язаність усіх складових частин тематичного матеріалу "Metamorphosis" Дж. Кейджа, які походять одна від одної 
та являють собою наочний процес перетворення однієї структури на іншу, відповідає динамічному процесу становлення музичного тексту, означеному М. Арановським за допомогою поняття лінгвіста Віктора Храковського «деривація», під яким розуміється «<..> перетворення однієї структури на іншу, де похідна структура за своїм граматичним статусом і сенсом відрізняється від вихідної» [1, с. 94.]

У фортепіанному циклі «Метаморфози» утілилися характерні особливості композиційного методу Дж. Кейджа, пов'язані з оновленням додекафонної системи, використанням техніки серійної фрагментації, застосуванням комбінаторики як важливого чинника трансформації й оновлення музичного матеріалу. Послідовне проведення принципу конструктивізму, що простежується як у структурній ясності, раціональній вивіреності музичної тканини, так і в довершеності музичної форми, своєрідно поєднується з особливостями музичного розвитку за принципом органічної прогресії, що приводить до послідовного нарощення тематичного матеріалу у процесі становлення композиції фортепіанного циклу.

У характеристиці композиційної техніки, продемонстрованої Дж. Кейджем у «Метаморфозах», можна зробити спробу вийти на міждисциплінарний рівень означеної проблематики та порівняти принципи роботи американського композитора і нідерландського графіка М.К. Ешера (1898-1972 рр.), відомого передусім своїми концептуальними гравюрами на дереві й металі (характерною рисою «сюжетів» яких є виявлення різного роду парадоксів, абсурду, ілюзії, з акцентом на смисловій багатозначності зображуваного матеріалу), а саме з його трьома панорамними літографіями «Метаморфози»у мозаїчних площинах, у яких представлений наскрізний процес трансформації вихідних геометричних форм та їх переходу в більш конкретні (предметні) образи (здебільшого зооморфні й антропоморфні).

У книзі «Гедель, Ешер, Бах: ця безкінечна блискуча гірлянда» американського фізика Д. Хофштадтера гравюра «Метаморфоза II» М.K. Ешера порівнюється 3 образами безкінечного руху, який також зображується в його картині «Підйом та спуск» [6, с. 45]. Д. Хофштадтер проводить аналогію між «Метаморфозою II» і музикою та посилається на творчий доробок Й.С. Баха. За його словами, гравюра «<...> трохи нагадує “Canon per tonos": відходячи все далі й далі від 
початкового пункту, ми несподівано повертаємося до початку. У площинах «Метаморфози» уже $є$ натяк на безкінечність, проте інші картини Ешера являють ще більш сміливі образи безкінечного» [6, с. 45].

Варто зазначити, що поступова змінність та деяка «наочність» зміни початкової структури (візуальної, геометричної в М.К. Ешера й аудіовізуальної, звукової у Дж. Кейджа) зближують творчі методи обох митців у представлених творах. Дані особливості відображають схожість концепції метаморфоз в обох циклах щодо розуміння самої ідеї видозміни як поступового, безкінечного процесу корінних перетворень вихідної структури, що й визначають ідею метаморфози як процесу кардинальних видозмін вихідного музичного матеріалу, результатом яких стає поява похідного, нового тексту. 3 позицій міждисциплінарних тенденцій XX-XXI ст. щодо явища тексту концепція метаморфози вбачається обширною віхою, що може стати спільною ланкою для означення актуальних проблем соціокультурного поля.

Приклад 9. М.К. Ешер. «Метаморфози II»
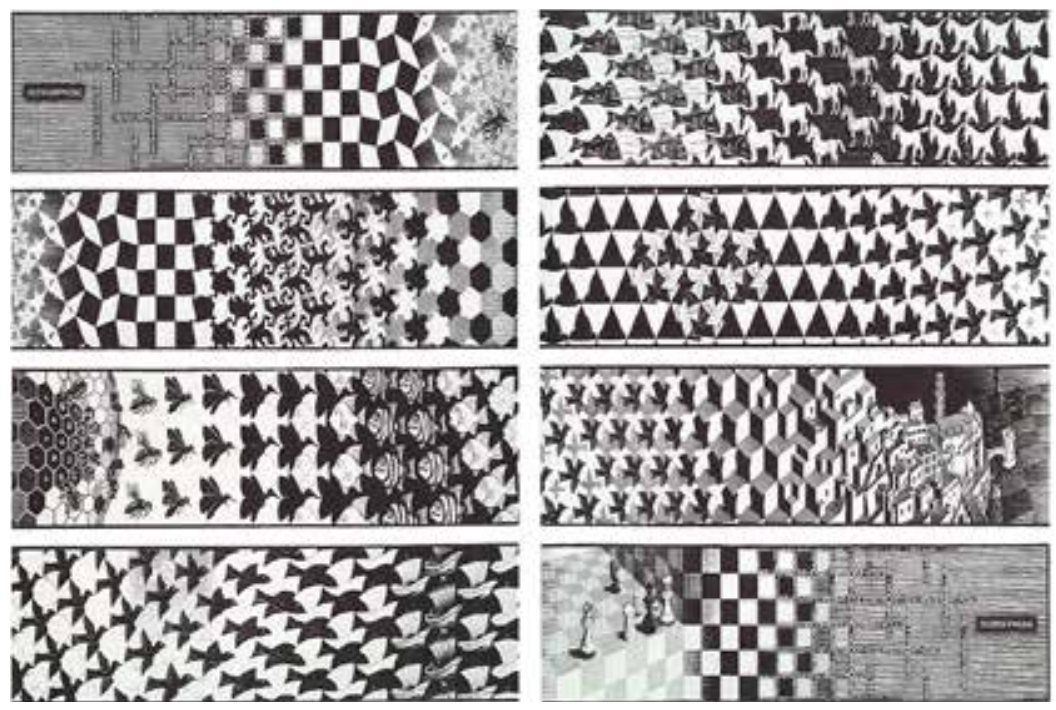

Розглянуті теоретичні аспекти концепції метаморфози висвітлюють іiі багатовекторність. Ця проблема охоплює широке коло питань, серед яких можна виокремити: 
1. Нові тенденції у сфері компонування музичних творів XX-XXI ст.

2. Специфіка тематичної організації опусів у творчості композиторів минулого століття та сучасності.

3. У композиціях П. Гінеміта, Л. Колодуба, Т. Конроя, В. Лютославського - проблема взаємодії «свого» та «чужого» тексту (що висвітлена у працях М. Арановського, А. Шнітке, Ю. Крістєвої й інших), формами запозичення музичного матеріалу і способами його перетворення.

Метаморфоза як явище і поняття актуальна для XX та початку XXI ст., про що свідчить іiі поширеність у композиторській практиці та музикознавчих роботах. Зважаючи на це, дана концепція потребує теоретичного обгрунтування та подальшого всебічного вивчення, адже цей термін має давню історію вживання (поеми Овідія, Апулея, праці І. Гете, К. Ліннея, твори М.К. Ешера, П. Пікассо тощо), а також усталене смислове значення, що дозволяє використовувати його як у спеціалізованій сфері теоретичного музикознавства, так і в міждисциплінарних, інтермедіальних дослідженнях актуальних соціокультурних, мистецьких проблем XX-XXI ст.

\section{СПИСОК ЛІТЕРАТУРИ}

1. Арановский М. Музыкальный текст. Структура и свойства. Москва, 1998. 343 с. $376 \mathrm{c}$.

2. Асафьев Б. Музыкальная форма как процесс. Ленинград, 1971.

3. Григоренко Е. Джон Кейдж. Творчество. Киев, 2012. 226 с.

4. Левитин К. Геометрическая рапсодия. Москва, 2004. 216 с.

5. Переверзева М. Дж. Кейдж: жизнь, творчество, эстетика Москва, 2006. 333 с.

6. Хофштадтер Д. Гедель, Эшер, Бах. Эта бесконечная гирлянда. Самара, 2001. 752 с.

\section{REFERENCES}

1. Aranovsky M. (1998) Musical text. Structure and properties. Moscow [in Russian].

2. Asaf'ev B. (1971) Musical form as a process. L. [in Russian].

3. Grigorenko E. (2012) John Cage. Creativity. Kyiv [in Russian].

4. Levitin K. (2004) Geometric rhapsody. Moscow [in Russian].

5. Pereverzeva M. (2006) J. Cage: life, creativity, aesthetics. Moscow [in Russian].

6. Hofstadter D. (2001) Gцdel, Escher, Bach. This endless garland. Samara [in Russian]. 